\title{
Clinicopathological Pattern of Penile Cancer in a Tertiary Care Centre in Nepal
}

Dipesh Kumar Gupta, 'Bhoj Raj Luitel, ${ }^{1}$ Pawan Raj Chalise, ${ }^{1}$ Pradeep Prasad Subedi,, Suman Chapagain, 1 Dipak Kumar Thakur, ' Uttam Kumar Sharma, ${ }^{1}$ Prem Raj Gyawali, ${ }^{1}$ Guna Kumar Shrestha'

'Department of Surgery, TUTH, IOM, Kathmandu, Nepal.

\section{ABSTRACT}

Introduction: Carcinoma of penis is an uncommon entity. The higher incidence in developing country may be because of poor hygiene, less common practice of circumcision and unsafe sexual practice. Timely diagnosis and intervention gives the patient a chance of cure. Data on penile cancer is sparse from Nepal so treatment of penile cancer in our centre is presented here.

Methods: This was a retrospective cross-sectional study done at Urology unit of Department of Surgery of Tribhuvan University Teaching Hospital, Nepal from November, 2007 to December, 2013. Data was retrieved from case records and those with penile carcinoma were included. Patient demographics, lesion characteristics, mode of treatment with outcome measures were noted and analyzed.

Results: Total 17 patients underwent treatment for primary penile lesion. Mean age of the patients was 51.5 years. Penile growth was the most frequent presentation with five patients coming with more than one symptom. The most common site was over glans of penis $(n=13)$ with the mean size of $3.55 \mathrm{~cm}$. Partial penectomy was offered in 16 with one patient undergoing circumcision only. Inguinal lymph node dissection was done in four patients. Squamous cell carcinoma was the histological diagnosis in 15 patients.

Conclusions: Penile carcinoma is primarily a disease of old. Growth over glans penis is the most common presentation and partial penectomy is feasible in most of the patients to allow oncological cure while preserving the organ for its native function.

Keywords: inguinal lymph node dissection; partial penectomy; penile cancer.

\section{INTRODUCTION}

Carcinoma of penis is uncommon in developed countries with an incidence of $0.4-0.6 \%$ of all cancers but in developing nations the incidence is as high as $10-20 \% .^{1-3}$ This is probably owing to poor hygiene, uncommon practice of circumcision, and unsafe sexual practice leading to infection with human papillomavirus. ${ }^{4}$
Because of social taboo, educational background and delay from practitioners, early diagnosis is missed. . $^{5-6}$

Timely diagnosis can save the organ with evolving techniques of penile preserving therapies. ${ }^{7-10}$ Surgery is

Correspondence: Dr. Dipesh K. Gupta, Urology Unit, Department of Surgery, TUTH, IOM, Kathmandu, Nepal. Email: drdipeshgupta@ yahoo.com, Phone: +977-9848070454. 
the only answer to the cure of the disease sometimes, while management of the node is another critical step. ${ }^{11}$

The burden of the disease is undefined in our country. So, the aim of this study was to determine the scenario of carcinoma of penis in our institution and treatment outcome in our context.

\section{METHODS}

A retrospective cross-sectional study was done at Urology unit, Department of Surgery, Tribhuvan University Teaching Hospital, a tertiary care hospital in Nepal from November, 2007 to December, 2013 as documents prior to this could not be retrieved. Ethical approval was obtained from the Institutional Review Board. The medical records of patients presenting with biopsy proven penile mass were included. Those who deferred treatment were excluded. Individual patient demographics, lesion characteristics, the type of primary treatment along with treatment of the lymph node and their outcome were analyzed using Microsoft Excel 2007.

\section{RESULTS}

There were total seventeen patients who were diagnosed to have carcinoma of penis by wedge biopsy of the penile lesions. Mean age of the patients was 51.5 years, with the largest number of patients in 50-60 age groups. The youngest patient aged 28 years (Figure 1 ). Six of the patients were active smokers.

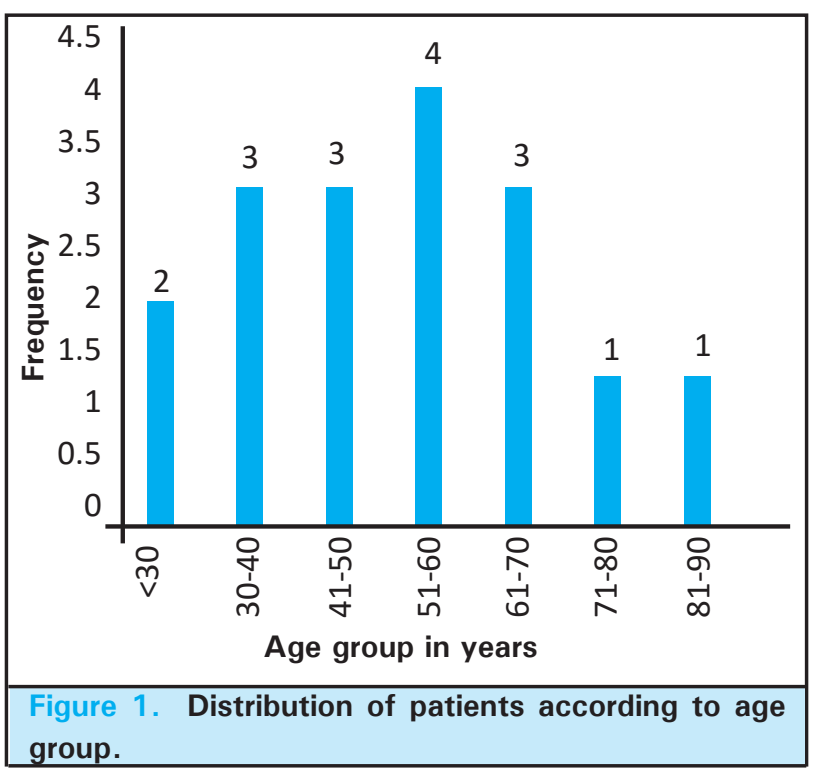

Thirteen patients presented with a growth and five of them had an ulcer including one with an ulcerated growth. Three patients presented with urinary symptoms such as spraying of the urine while micturating. Median duration of the symptoms was six months with one patient presenting with prolonged duration of symptoms for nine years (Table 1 ).

\begin{tabular}{|cl|}
\hline \multicolumn{2}{|l|}{ Table 1. Patient characteristics. } \\
Characteristics & $\mathrm{n}(\%)$ \\
Growth & $13(76.47)$ \\
Ulcer & $5(29.41)$ \\
Discharge & $3(17.64)$ \\
Pain & $4(23.54)$ \\
Bleeding & $1(5.90)$ \\
Urinary symptoms & $3(17.64)$ \\
More than one symptom & $5(29.41)$ \\
Location of the lesion & $2(11.76)$ \\
Prepuce & $12(70.58)$ \\
Glans penis & $2(11.76)$ \\
Glans and prepuce & $1(5.90)$ \\
Shaft of penis & 17 \\
\hline
\end{tabular}

Mean size of the growth was $3.55 \mathrm{~cm}$. The most common location was over glans of penis. Four of the patients had palpable superficial inguinal group of lymph nodes on examination.

Surgical treatment of the patients consisted mainly of partial penectomy. Sixteen patients underwent this modality with three patients undergoing modified inguinal lymph node dissection who were having palpable lymph nodes suggestive of metastasis and those who were proved to have lesion T2 or above.

Histopathologically, verrucous carcinoma was found in two patients while 15 patients had squamous cell carcinoma. Eleven patients had well differentiated carcinoma. One patient had positive tumor margin for which redo surgery was done. Eight patients were found to have T2 disease (Table 3). Nodal involvement could not be determined in 13 patients either because of poor follow up or patients deferring treatment. Each category of NO, N1, N2 and N3 consisted of one patient, respectively. 


\begin{tabular}{|ll|}
\hline \multicolumn{2}{|c|}{ Table 2. Surgical modality of the primary lesion. } \\
\hline Treatment modality & $\mathrm{n}(\%)$ \\
Circumcision & $1(5.90)$ \\
Partial penectomy & 13 \\
Partial penectomy with lymph node & $(76.47)$ \\
dissection & $3(17.64)$ \\
\hline
\end{tabular}

\begin{tabular}{|ll|}
\hline Table 3. Stage of disease. \\
\hline T stage & $\mathrm{n}(\%)$ \\
Tis & $2(11.76)$ \\
Ta & $2(11.76)$ \\
T1a & $3(17.64)$ \\
T1b & $1(5.90)$ \\
T2 & $8(47.05)$ \\
T3 & $1(5.90)$ \\
Total & 17 \\
\hline
\end{tabular}

\section{DISCUSSION}

Penile cancer is more common in those aged $50-57$ years. ${ }^{12}$ However, incidence can be as high as $22 \%$ in those less than 40 years of age and $7 \%$ in those younger than 30 years. ${ }^{13}$ The mean age of the patients in our series was 51.5 yrs with those under 40 years of age being five in number (29\%). The result is consistent with the literature. ${ }^{12}$ Six of our patients were active smokers. The role of tobacco as potential etiological factor has been considered to be very strong though the exact mechanism is not known. ${ }^{14-16}$

Growth in the genitalia was most frequent presentation. Narayana AS et al observed similar findings. ${ }^{3}$ Median duration since symptom initiation was six months. It may be because of unusual slow growth pattern of lower grade tumours as well as embarrassment, fear, personal neglect and ignorance on patients' part as the possible causes.
Treatment of penile cancer remains a controversial topic, however, there is general agreement so as to prefer organ preserving. ${ }^{17}$ Nevertheless, surgical amputation of the primary tumour remains the oncologic gold standard. Local recurrence can range from $0-8 \% .{ }^{13}$ One patient underwent circumcision only for growth over prepuce. Squamous cell carcinoma was the most frequent histopathological variant in our series which is similar to other studies. ${ }^{18}$ In our series eight of the patients had T1 or lower stage while eight patients had T2 disease. Nodal dissection was carried out in four patients while other four patients deferred or lost to follow up. Other series also quote the occurrence of T1 stage to be more than T2; $70 \%$ versus $19 \%$, respectively. ${ }^{1}$ Our series had well differentiated tumour incidence to be 11 out of 17 patients. In one of the studies the incidence of well differentiated tumour was $43 \%$ while moderately differentiated pattern was seen in $35 \% .{ }^{1}$ Non industrialized countries show less incidence of poorly differentiated pattern in the range of $10-14 \% .{ }^{19-20}$ Our series exhibits the same pattern.

Management of the inguinal lymph node is supposed to be the most crucial step. However, morbidity related to the procedure is one factor that leads this options less desirable in all. ${ }^{21}$ Our series contained fewer patients with lymph node dissection. This is probably due to patients losing follow up after satisfactory treatment of the primary penile growth not realizing the prognosis in the absence of second procedure, or on physicians' part who were unable to convince patient for the second staged procedure. ${ }^{22}$ Low socioeconomic status and illiteracy plays a dominant role for incompletion of the

desired therapy.

\section{CONCLUSIONS}

Penile carcinoma is primarily a disease of old. Growth over glans penis is the most common presentation and partial penectomy is feasible in most of the patients to allow oncological cure while preserving the organ for its native function.

\section{REFERENCES}

1. Munro NP, Thomas PJ, Deutsch GP, Hodson NJ. Penile cancer: a case for guidelines. Ann R Coll Surg Engl. 2001 May;83(3):180-5.

2. Deem S, Keane T, Bhavsar R, El-Zawahary A, Savage S. Contemporary diagnosis and management of squamous cell carcinoma (SCC) of the penis. BJU Int. 2011 Nov;108(9):1378-92.
3. Narayana AS, Olney LE, Loening SA, Weimar GW, Culp DA. Carcinoma of the penis: analysis of 219 cases. Cancer. 1982 May 15;49(10):2185-91.

4. Harish K, Ravi R. The role of tobacco in penile carcinoma. Br J Urol. 1995 Mar;75(3):375-7.

5. Crispen PL, Mydlo JH. Penile intraepithelial neoplasia and other premalignant lesions of the penis. Urol Clin North Am. 2010 Aug;37(3):335-42. 
6. Tietjen DN, Malek RS. Laser therapy of squamous cell dysplasia and carcinoma of the penis. Urology. 1998 Oct;52(4):559-65.

7. Brkovic D, Kalble T, Dorsam J, Pomer S, Lotzerich C, Banafsche R, et al. Surgical treatment of invasive penile cancer--the Heidelberg experience from 1968 to 1994. Eur Urol. 1997;31(3):339-42.

8. Mohs FE, Snow SN, Messing EM, Kuglitsch ME. Microscopically controlled surgery in the treatment of carcinoma of the penis. J Urol. 1985 Jun;133(6):961-6.

9. Bandieramonte G, Lepera P, Marchesini R, Andreola S, Pizzocaro G. Laser microsurgery for superficial lesions of the penis. J Urol. 1987 Aug;138(2):315-9.

10. Shirahama $T$, Takemoto $M$, Nishiyama $K$, Nobori $T$, Kawahara M, Ohyama M, et al. A new treatment for penile conservation in penile carcinoma: a preliminary study of combined laser hyperthermia, radiation and chemotherapy. Br J Urol. 1998 Nov;82(5):687-93.

11. Theodorescu D, Russo P, Zhang ZF, Morash C, Fair WR. Outcomes of initial surveillance of invasive squamous cell carcinoma of the penis and negative nodes. J Urol. 1996 May;155(5):1626-31.

12. Barnholtz-Sloan JS, Maldonado JL, Pow-sang J, Giuliano AR. Incidence trends in primary malignant penile cancer. Urol Oncol. 2007 Sep-Oct;25(5):361-7.

13. Pettaway CA, Lance RS, Davis JW. Tumors of the Penis. In: Kavoussi LR, Partin AW, Novick AC, Peters CA, editors. Campbell's Urology. Vol 1. 10 ed. Philadelphia, PA: Saunders Elsevier; 2012. p. 901-33.

14. Daling JR, Madeleine MM, Johnson LG, Schwartz SM, Shera KA, Wurscher MA, et al. Penile cancer: importance of circumcision, human papillomavirus and smoking in in situ and invasive disease. Int J Cancer. 2005 Sep 10;116(4):606-16.
15. Koifman L, Vides AJ, Koifman N, Carvalho JP, Ornellas AA. Epidemiological aspects of penile cancer in Rio de Janeiro: evaluation of 230 cases. Int Braz J Urol. 2011 Mar-Apr;37(2):231-40; discussion 40-3.

16. Chaux A, Netto GJ, Rodriguez IM, Barreto JE, Oertell J, Ocampos S, et al. Epidemiologic profile, sexual history, pathologic features, and human papillomavirus status of 103 patients with penile carcinoma. World J Urol. 2013 Aug;31(4):861-7.

17. Chacko RT. Penile carcinoma: The Role of chemotherapy. Indian Journal of Urology. 2006;22(4):360-3.

18. Cubilla AL. The role of pathologic prognostic factors in squamous cell carcinoma of the penis. World J Urol. 2009 Apr;27(2):169-77.

19. Heyns CF, van Vollenhoven P, Steenkamp JW, Allen FJ. Cancer of the penis--a review of 50 patients. S Afr J Surg. 1997 Aug;35(3):120-4.

20. Ornellas AA, Seixas AL, Marota A, Wisnescky A, Campos F, de Moraes JR. Surgical treatment of invasive squamous cell carcinoma of the penis: retrospective analysis of 350 cases. J Urol. 1994 May;151(5):1244-9.

21. Bhagat SK, Gopalakrishnan G, Kekre NS, Chacko NK, Kumar S, Manipadam MT, et al. Factors predicting inguinal node metastasis in squamous cell cancer of penis. World J Urol. 2010 Feb;28(1):93-8.

22. Rangabashyam N, Gnanaprakasam D, Meyyappan P, Vijayalakshmi SR, Thiruvadanam BS. Carcinoma of penis. Review of 214 cases. J R Coll Surg Edinb. 1981 Mar;26(2):104-9. 